\title{
Providing a model for understanding the phenomenon of employees' laziness among \\ Iranian governmental organizations
}

Mohsen Emamverdi

Ph.D Student in Organizational Behavior Management, Aras International Campus, University of Tehran, Iran

mohsen_emamverdi@yahoo.com

Hasan Zarei Matin

Professor of Management, Aras International Campus, University of Tehran, Iran maten@ut.ac.ir

Seyed Reza Sayed Javadin

Professor of Management, Aras International Campus, University of Tehran, Tehran, Iran javadin@ut.ac.ir

\section{Editor Científico: José Edson Lara \\ Organização Comitê Científico \\ Double Blind Review pelo SEER/OJS \\ Recebido em 05.05.2019 \\ Aprovado em 22.06.2019}

Este trabalho foi licenciado com uma Licença Creative Commons - Atribuição - Não Comercial 3.0 Brasil 


\begin{abstract}
The present study was to provide a model for understanding the phenomenon of employees' laziness among Iranian governmental organizations. This research is an applied one in terms of purpose and an exploratory-survey one in terms of approach. The statistical population of the research was selected among a group of experts in human resource composed of executive directors specializing in human resources who were interviewed in-depth. This selection and conduct of the interview continued until the theoretical saturation, and then stopped. In this study, the snowball sampling method was used. In this way, the first expert was selected according to initial investigations and surveys of the honorable supervisor. After completing the interview with the first person, he was asked to introduce other expert or experts who may be experts in the field of employees' laziness and contribute to the richness of the research model. This process continued until the researcher theoretical saturation. Eventually, 16 experts were interviewed. In this research, since the grounded theory method was used, the main tools for data collection were in-depth and unstructured interviews with human resources experts. Finally, after three stages coding include open, axial and selective, a conceptual model of research was designed based on the paradigmatic model.
\end{abstract}

Keywords: employees' laziness, Iranian governmental organizations.

\title{
Fornecendo um modelo para entender o fenômeno da preguiça de funcionários entre organizações governamentais iranianas
}

\section{Resumo}

O presente estudo foi para fornecer um modelo para a compreensão do fenômeno da preguiça dos funcionários entre as organizações governamentais iranianas. Esta pesquisa é aplicada em termos de propósito e uma pesquisa exploratória em termos de abordagem. A população estatística da pesquisa foi selecionada entre um grupo de especialistas em recursos humanos composto por diretores executivos especializados em recursos humanos que foram entrevistados em profundidade. Essa seleção e condução da entrevista continuaram até a saturação teórica, e então pararam. Neste estudo, foi utilizado o método de amostragem bola de neve. Desta forma, o primeiro especialista foi selecionado de acordo com as investigações iniciais e pesquisas do honroso supervisor. Depois de concluir a entrevista com a primeira pessoa, ele foi convidado a apresentar outro especialista ou especialistas que possam ser especialistas no campo da preguiça dos funcionários e contribuir para a riqueza do modelo de pesquisa. Esse processo continuou até a saturação teórica do pesquisador. Eventualmente, 16 especialistas foram entrevistados. Nesta pesquisa, desde que o método da teoria fundamentada foi utilizado, as principais ferramentas para coleta de dados foram entrevistas em profundidade e não estruturadas com especialistas em recursos humanos. Finalmente, após três estágios de codificação incluem aberto, axial e seletivo, um modelo conceitual de pesquisa foi projetado com base no modelo paradigmático.

Palavras-chave: preguiça de empregados, organizações governamentais iranianas 


\section{Proporcionar un modelo para comprender el fenómeno de la pereza de los empleados entre las organizaciones gubernamentales iraníes}

\section{Resumen}

El presente estudio proporcionó un modelo para comprender el fenómeno de la pereza de los empleados entre las organizaciones gubernamentales iraníes. Esta investigación es una aplicada en términos de propósito y una encuesta exploratoria en términos de enfoque. La población estadística de la investigación fue seleccionada entre un grupo de expertos en recursos humanos compuesto por directores ejecutivos especializados en recursos humanos que fueron entrevistados en profundidad. Esta selección y conducción de la entrevista continuó hasta la saturación teórica, y luego se detuvo. En este estudio, se utilizó el método de muestreo de bola de nieve. De esta manera, el primer experto fue seleccionado de acuerdo con las investigaciones iniciales y las encuestas del supervisor honorable. Después de completar la entrevista con la primera persona, se le pidió que presentara a otros expertos o expertos que puedan ser expertos en el campo de la pereza de los empleados y que contribuyan a la riqueza del modelo de investigación. Este proceso continuó hasta la saturación teórica del investigador. Finalmente, 16 expertos fueron entrevistados. En esta investigación, desde que se usó el método de la teoría fundamentada, las herramientas principales para la recopilación de datos fueron entrevistas exhaustivas y no estructuradas con expertos en recursos humanos. Finalmente, después de tres etapas de codificación que incluyen abierta, axial y selectiva, se diseñó un modelo conceptual de investigación basado en el modelo paradigmático.

Palabras clave: pereza de los empleados, organizaciones gubernamentales iraníes.

\section{Introduction}

Today, the most important and valuable asset of any organization is its employees, because the success or failure of all management plants depend on its employees. As a result, human capital, which deals with the employment, training and maintenance of employees, now has the best chance of becoming one of the most important management strategies from the margin of organizational strategies. In the perspective of strategic management of human capital, all the knowledge and skills existing in the organization are not considered strategic. Then, determining the types of human capital in the organization and how to apply them as the source of competitive advantage is the first step in this way. Taking a resource-based look at the organization, we find that resources are only valuable to us when they cause increasing efficiency and allow us to invest in opportunities and to confront threats. So, in this view, the human capital of the organization create value through the cooperation in reducing costs or improving the services and products for customers (Jazani, 2015). However, many pests are ambushing behind this huge organizational capital. 
One of the challenges recently faced by organizations is individual laziness in the organization. In an organization in which laziness penetrates, its employees are always put today's work to tomorrow to do small and big affairs in their personal, professional and public life; they leave the decision to others; they wish the changes except from others - without the least action; they do not have the habit of thinking and delay for any selection. Naturally, in such an organization, the amount of production and work efficiency is very low, and there is little interest and willingness to work. Construction proceeds slowly and time is not of real value. In spite of the great importance of organizational laziness, there has not been any research or even a comprehensive paper on organizational laziness in Iran (Sepahvand and Mohammadyari, 2015).employees' laziness is the gap between the intentions of doing work and behavior, and it is mentioned as delaying and replacing the necessary assignments by performing other unnecessary activities. Laziness is to avoid starting and continuing work. Laziness means not doing work and opposition to work (Sepahvand and Mohammadyari, 2015). It is difficult to find a comprehensive definition that can cover laziness meaning, and it is close to sloth, indolence (positive meaning), fatigue, idleness, passivity, or even lethargy that stem from Christian thoughts. Two essential elements are distinct in the definition of employees' laziness: first, the employees' laziness is a syndrome that causes many physical and mental harm to the person, and secondly, the person irrationally avoid a particular work or task. Overall, laziness is to delegate something to the future that a person refuses to do for any rational or irrational reason. That is why, the employees' laziness is often associated with psychological distress and suffering (Fayazi, 2009). Recent studies have also shown that employees' laziness has a negative impact on their productivity, physical health, nutritional habits and exercise. employees' laziness is resulted by the absence or lack of motivation. From an organizational perspective, laziness is an enemy of the organization and prevents the growth of productivity and creativity. Laziness at work is a targeted delay in starting or completing various job assignments (Wohl, 2010).

According the above mentioned, one of the factors affecting the performance of governmental organizations is the presence of skilled and capable employees. In governmental organizations, most services are provided by human resources and resource mobilization at the level of global standards requires skilled and trained personnel. In technical dimension, employees must have the ability to use new technology and be professional in their job; in the human dimension, employees must be able to interact and communicate in the best way with 
the clients, and in the perceptual dimension, the human resources must also identify, analyze and solve the clients' problems. In fact, in direction of clients satisfaction, the main point is the speed and accuracy of services provided and the timely fulfillment of obligations by government organizations. In the general policies of the administrative system communicated by the Supreme Leader, out of a total of 26 clauses, in two of them (clauses 11 and 12), increasing effectiveness and efficiency in administrative processes and procedures are considered in order to accelerate and facilitate the provision of national services. Also, in Articles 36 and 90 of the Civil Service Management Act, executive agencies and employees are required to implement the processes and procedures for doing their job to increase human resource productivity and the effectiveness of activities such as speed, accuracy, and so on. According to the results of the Labor Force Survey in 2011, released by the Statistical Center of Iran, the annual labor productivity per capita in Iran is 800 hours; while it is 2,420 hours in Japan, 1,900 hours in South Korea, 1,660 hours in the United States, 1,330 hours in Turkey, 1,100 hours in Pakistan, 1,700 hours in Germany, and 950 hours in Afghanistan. Statistical Center reports also show that Iran's human resources productivity index is very low compared to countries in the region and East Asia. Initial interviews with many government executives indicated that most of them were struggling with employee's laziness in collection under their management and in their opinion, the employees' laziness has caused various problems, including reducing the clients' satisfaction, increasing the clients' complaints, increasing work stress and tensions between colleagues, and so on. The conducted reviews determined that there has not been comprehensive and complete research on this pervasive problem in Iranian governmental organizations and its various antecedents and aftermath aspects are unclear for mangerss of the country's governmental organizations. So, present study is to answer the following question by designing and implementing a fully scientific and precise methodology: "How is the model for understanding the phenomenon of employees' laziness among Iranian governmental organizations?"

\section{The importance and necessity of research}

Postponing works not only results in the loss of efficiency, but also causes regrets and reduces self-confidence. This behavioral style is the easiest way to escape from problems and responsibilities, but its end to hard and full of sorrow, since it makes works more complicated and increases the work pressure, and sometimes it is impossible to do works 
and compensates resulting from the accumulated and abandoned works. Procrastination is one of the greatest obstacles to progress that does not allow a person to progress in life and work with dynamism and vitality, and he/she always stagnates (Shul, 2013).It is important and necessary to conduct this research both theoretically and practically. Theoretically, given the lack of studies in the field of human resources management for governmental organizations on employees' laziness modeling, this research can partly help to overcome this vacuum and to model it in this regard. Also practically, it seems that the model obtained by this research can show the different aspects of the phenomenon of employees' laziness in governmental organizations more clearly to relevant managers and help them manage, control and reduce this problem. With this regard, this study has sufficient necessity and importance.

\section{Literature review}

Sepahvand and Mohammadyari (2015) conducted a research titled "Identification of the Mentality of Individuals Towards Organizational Laziness Using Q-methodology". The main purpose of this research was to identify the mentality of individuals toward organizational laziness in governmental organizations in Ilam. The methodology used in this research is Qmethodology, which is a mixed (qualitative-quantitative) method. The statistical population consisted of managers of governmental organizations in Ilam. For sampling, 10 specialist, familiar and working managers in governmental organizations of Ilam city were selected. The results indicate that managers of governmental organizations in Ilam have three mental models in relation to organizational laziness in governmental organizations, including: employees (individual factors), organization (organizational factors) and the nature of government jobs.

Government jobs generally tend to be monotonous, tedious, and boring, which will put employees at job burnout. The monotony of these jobs and the burnout caused by them have negative consequences, including the separation of individual and organizational goals, and resistance to any kind of job change that makes employees feel discouraged, job dissatisfaction and fatigue, and leads the organizational laziness through under-activation, evading work, deferring assigned tasks and lack of sufficient accuracy at works.

Hajizadeh Ebrahimi (2015) conducted a research titled "The Study of Impact of Knowledge Management on the Trust and Social loafing of Mellat Bank Employees". The purpose of this 
research was to investigate the relationship between sharing and applying knowledge, trust and social loafing among employees of Mellat Bank in Mazandaran province.

The statistical population of this study included all 1100 employees of this bank. According to the Morgan table, the minimum sample size for this study was 285 people. Sampling method in this study was a systematic random one. Among 400 questionnaires distributed among the employees, 296 questionnaires were usable and the rest were excluded from the analysis. The study was conducted using descriptive-correlational method and a researcher-made questionnaire was used to collect data. Data analysis in this study has shown that social loafing has a negative and significant relationship by sharing and applying knowledge and trust among employees. The results suggest that organizations need to increase trust among employees through sharing and applying knowledge. This will have a significant impact on the reduction of employees' social loafing, and ultimately result in an increase in employee productivity and providing better services for customers.

Yekkeh Fallah et al. (2016) conducted a research titled "The Effectiveness of Treatment Based on Islamic Teachings and Concepts in Reducing Procrastination". The abstract of an article derived from this study states: "The purpose of this study was to determine the effectiveness of treatment based on Islamic teachings and concepts of in reducing procrastination. This study was single-subject multiple baseline experimental design that was run on a second-grade secondary school boy student for 8 sessions per week. In order to collect data, the client completed the Tuckman Procrastination Survey (TPS) (1991), in the baseline stage (pre-test), the assessment of four stages (post-test) and one month after treatment (followup) period. The data were collected using clinical interview and procrastination scale, and the graphical analysis was used for data analyze. The results indicated that treatment based on Islamic teachings and concepts has a positive effect on reducing procrastination and a 55/76 percent recovery was obtained for the student. These effects remain in the follow-up period to a large extent".

Zhenpeng Luo et al. (2013) conducted a research titled "Justice Perceptions and Drives of Hotel Employee Social loafing Behavior". The purpose of this study was to investigate the effect of employees' perceptions of organizational justice on their social loafing behaviors and it was conducted on 585 employees from 43 hotels in China. Finally, the results of the research showed that employees' perceptions of organizational justice have a negative and decreasing effect on their manifested social loafing behaviors. 
Fang Chen et al. (2014) conducted a research titled "How Much Has my Co-worker Contributed? The Impact of Anonymity and Feedback on Social Loafing in Asynchronous Virtual Collaboration". This research was conducted with the aim of investigating the effect of how to provide feedback to individuals and the anonymity of individuals (in cyberspace) on social loafing behavior in virtual asynchronous collaborations. Finally, the results showed that one of the reasons for the occurrence of social loafing behavior in virtual asynchronous collaborations is the anonymity of individuals.

Metin et al. (2016) carried out a study titled "Measuring Procrastination at Work and Its Associated Workplace Aspects" in Turkey and the Netherlands. This study was conducted with three objectives: (1) providing a new tool for coping with job procrastination; (2) examining the structure of the procrastination; and (3) conducting an experimental research with a communicative approach between variables of procrastination, characteristics of work environment, fatigue and work reverse behaviors. In this study, a sample of 384 people was used to collect data. For statistical analysis, structural equation modeling and Lisrel software were used. Finally, the results stated that there was a significant relationship between low level job requirements and job burnout, and in addition, there was a significant relationship between job burnout and procrastination.

\section{Research Methodology}

The present study is an applied one in terms of purpose and an exploratory-survey one in terms of approach.

In this research, a group of experts in human resource were selected composed of executive directors specializing in human resources who were interviewed in-depth. This selection and conduct of the interview continued until the theoretical saturation, and then stopped. In this study, the snowball sampling method was used. In this way, the first expert was selected according to initial investigations and surveys of the honorable supervisor. After completing the interview with the first person, he was asked to introduce other expert or experts who may be experts in the field of employees' laziness and contribute to the richness of the research model. This process continued until the researcher theoretical saturation. Eventually, 16 experts were interviewed. 
Since the grounded theory method was used, the main tools for data collection were in-depth and unstructured interviews with human resources experts. In these interviews, the researcher tried to ask indirect questions on antecedents and backgrounds of employees laziness, the environmental factors affecting it, the consequences of this phenomenon in organizations and so on, by entering softly to discussion and gaining initial trust of the interviewees, and in this way, get the basic concepts for designing the model.

\section{Results}

\subsection{Open coding}

This stage of analysis was dedicated to identifying and extracting the basic concepts of the content of the interviews. Accordingly, after conducting each interview, the researcher extracted and encoded the concepts contained in the interview content with a multiple review of it. Of the total of 16 interviews, 93 basic concepts were extracted. After reviewing and removing repetitive concepts, 49 final concepts were identified, which can be seen in Tables 1-

4. (It is worth noting that the codes beside the concepts include a Latin word and a number, the Latin word (in alphabetical order) donates the name of the person interviewed, and the number beside it donates the number of the concept extracted from that particular interview).

\section{Table 1}

Finalized concepts after analyzing interviews and eliminating repetitive concepts in the open coding step

\begin{tabular}{|l|l|}
\hline \multicolumn{1}{|c|}{ Concept } & \multicolumn{1}{c|}{ Code } \\
\hline Being committed to work obligations toward the client & $\mathrm{A}_{1}, \mathrm{G}_{4}, \mathrm{M}_{5}$ \\
\hline Perceived organizational justice by employee & $\mathrm{B}_{1}, \mathrm{E}_{3}, \mathrm{~K}_{4}$ \\
\hline $\begin{array}{l}\text { The employee's belief in that he/she will be given more jobs if the } \\
\text { organization's tasks are carried out promptly }\end{array}$ & $\mathrm{A}_{2}, \mathrm{D}_{7}, \mathrm{I}_{7}$ \\
\hline $\begin{array}{l}\text { The organizational policies and strategies to combat employees' laziness } \\
\text { and procrastination }\end{array}$ & $\mathrm{A}_{3}, \mathrm{~B}_{6}, \mathrm{~F}_{3}, \mathrm{M}_{3}$ \\
\hline Timely performing organizational tasks & $\mathrm{D}_{1}, \mathrm{H}_{5}, \mathrm{~J}_{3}$ \\
\hline $\begin{array}{l}\text { The employee's personality characteristics consistency with his/her role in } \\
\text { the organization }\end{array}$ & $\mathrm{C}_{4}, \mathrm{~K}_{2}$ \\
\hline $\begin{array}{l}\text { The employee's ability to manage mental and psychological problems } \\
\text { during work }\end{array}$ & $\mathrm{E}_{1}, \mathrm{~K}_{6}, \mathrm{~L}_{3}, \mathrm{M}_{1}$ \\
\hline The manager's perception of employee's problems and challenges & $\mathrm{I}_{1}, \mathrm{~J}_{2}, \mathrm{M}_{6}$ \\
\hline Social solidarity and empathy perceived by employees & $\mathrm{A}_{10}$ \\
\hline Knowing the manager confidant to express work problems & $\mathrm{A}_{11}, \mathrm{C}_{5}, \mathrm{~F}_{9}$ \\
\hline Being committed to work obligations toward the manager & $\mathrm{A}_{8}, \mathrm{~F}_{7}, \mathrm{H}_{1}$ \\
\hline Being committed to work obligations toward the colleagues & $\mathrm{B}_{2}, \mathrm{D}_{4}, \mathrm{I}_{6}$ \\
\hline The employee's healthy and happy family life outside the organization & $\mathrm{D}_{3}, \mathrm{~L}_{2}$ \\
\hline $\begin{array}{l}\text { The employee's physical fitness conditions to complete full-time working } \\
\text { hours }\end{array}$ & $\mathrm{F}_{1}, \mathrm{G}_{6}, \mathrm{~K}_{1}$ \\
\hline
\end{tabular}




\begin{tabular}{|c|c|}
\hline $\begin{array}{l}\text { The senior management's attention to the laziness and procrastination of } \\
\text { employees in doing organizational works }\end{array}$ & $\mathrm{C}_{2}, \mathrm{~F}_{8}, \mathrm{I}_{3}$ \\
\hline $\begin{array}{l}\text { The employee's behavioral characteristics alignment with the atmosphere } \\
\text { and culture of the organizational unit }\end{array}$ & $\mathrm{F}_{2}, \mathrm{I}_{5}, \mathrm{~K}_{5}$ \\
\hline The organization's knowledge support of the employee & $\mathrm{D}_{2,} \mathrm{I}_{4}, \mathrm{M}_{2}$ \\
\hline $\begin{array}{l}\text { Doing right and consistent works with organizational goals throughout the } \\
\text { day }\end{array}$ & $\mathrm{A}_{9}, \mathrm{~J}_{5}$ \\
\hline $\begin{array}{l}\text { The employee's belief in that if the client's job is done fast, he/she will not } \\
\text { be grateful }\end{array}$ & $\mathrm{B}_{4}, \mathrm{H}_{2}, \mathrm{~L}_{1}$ \\
\hline The culture of being committed to job against the culture of dodge the job & $\mathrm{A}_{6}, \mathrm{D}_{5}, \mathrm{H}_{7}$ \\
\hline $\begin{array}{l}\text { Organization's careful monitoring to prevent laziness and procrastination of } \\
\text { employees in doing their job }\end{array}$ & $\mathrm{C}_{3}, \mathrm{G}_{2}, \mathrm{~J}_{1}$ \\
\hline The employee's economic concerns for livelihood & $\mathrm{A}_{5}, \mathrm{E}_{6}, \mathrm{E}_{2}, \mathrm{M}_{8}$ \\
\hline Organizational intellectual and mental support of the employee & $\mathrm{A}_{7}, \mathrm{C}_{6}, \mathrm{G}_{3}$ \\
\hline The employee's normal conditions psychologically & $\mathrm{B}_{5}$ \\
\hline The employee's satisfaction with salary policies & $\mathrm{B}_{3}, \mathrm{D}_{8}, \mathrm{M}_{7}$ \\
\hline The employee's satisfaction with the manager & $\mathrm{E}_{4}, \mathrm{~K}_{3}$ \\
\hline The employee's very low useful working time during a day & $\mathrm{B}_{7}, \mathrm{H}_{4}, \mathrm{I}_{2}$ \\
\hline Known the manager confidant to express personal and family problems & $\mathrm{G}_{1}, \mathrm{I}_{8}, \mathrm{M}_{4}$ \\
\hline Right and accurate work doing & $\mathrm{C}_{7}, \mathrm{~F}_{4}$ \\
\hline No acute and chronic illness for employee & $\mathrm{D}_{6}, \mathrm{E}_{5}, \mathrm{G}_{5}, \mathrm{~J}_{4}, \mathrm{~L}_{4}$ \\
\hline Spending time outside the organization accompanied by the manager & $\mathrm{C}_{1}, \mathrm{~F}_{6}, \mathrm{H}_{6}$ \\
\hline The employee's satisfaction with colleagues & $\mathrm{F}_{5}, \mathrm{I}_{9}$ \\
\hline Fairness of the payroll system & $\mathrm{O}_{1}$ \\
\hline Considering bonuses for efficient employees & $\mathrm{O}_{2}, \mathrm{P}_{4}$ \\
\hline $\begin{array}{l}\text { The senior employees belief in that much work does not lead to material } \\
\text { and spiritual rewards in the organization }\end{array}$ & $\mathrm{P}_{3}, \mathrm{~N}_{2}$ \\
\hline The senior employees belief in that their efforts are not seen & $\mathrm{O}_{4}, \mathrm{P}_{7}$ \\
\hline Achieving career goals & $\mathrm{P}_{5}$ \\
\hline The employees' clear goals and career path & $\mathrm{P}_{6}$ \\
\hline The employees' appropriate guidance & $\mathrm{O}_{7}$ \\
\hline The employees' participation in decision-making processes & $\mathrm{P}_{8}$ \\
\hline Paying attention to the efforts of employees by managers & $\mathrm{O}_{9}$ \\
\hline Considering incentives for efficient employees & $\mathrm{P}_{9}, \mathrm{O}_{3}, \mathrm{~N}_{5}$ \\
\hline The existence of fair rules and regulations in the organization & $\mathrm{O}_{8}, \mathrm{~N}_{4}$ \\
\hline Considering employees' work effects & $\mathrm{N}_{6}$ \\
\hline Existence of appropriate strategies and programs & $\mathrm{P}_{2}, \mathrm{O}_{5}$ \\
\hline Determining group and individual goals by managers & $\mathrm{P}_{1}, \mathrm{O}_{6}, \mathrm{~N}_{3}$ \\
\hline $\begin{array}{l}\text { Delegation of authority and supporting innovative ideas of employees in } \\
\text { the organization }\end{array}$ & $\mathrm{N}_{7}, \mathrm{O}_{10}$ \\
\hline Providing information and funding & $\mathrm{N}_{1}$ \\
\hline
\end{tabular}

\subsection{Axial coding and selective coding}

At this stage, we tried to create a more general category called "categories" with a deep attention to identified concepts and specifying similarities and differences between them, and to put congruent concepts in these more general categories. The result of this process was the identification of 18 main categories, which can be seen in Table 2, along with the related concepts: 
Table 2

Identified categories with relevant concepts

\begin{tabular}{|c|c|c|}
\hline Concept (open coded) & $\begin{array}{c}\text { Category (axial } \\
\text { encoding) }\end{array}$ & Row \\
\hline Being committed to work obligations toward the manager & \multirow{3}{*}{$\begin{array}{l}\text { The employee's } \\
\text { organizational } \\
\text { commitment }\end{array}$} & \multirow{3}{*}{1} \\
\hline $\begin{array}{l}\text { Being committed to work obligations toward the } \\
\text { colleagues }\end{array}$ & & \\
\hline Being committed to work obligations toward the client & & \\
\hline The employee's economic concerns for livelihood & \multirow{3}{*}{$\begin{array}{l}\text { Cultural, social and } \\
\text { economic factors of } \\
\text { society }\end{array}$} & \multirow{3}{*}{2} \\
\hline Social solidarity and empathy perceived by employees & & \\
\hline $\begin{array}{l}\text { The culture of being committed to job against the culture } \\
\text { of dodge the job }\end{array}$ & & \\
\hline $\begin{array}{l}\text { Spending time outside the organization accompanied by } \\
\text { the manager }\end{array}$ & \multirow{4}{*}{$\begin{array}{l}\text { The quality of the } \\
\text { employee's relationship } \\
\text { with the manager }\end{array}$} & \multirow{4}{*}{3} \\
\hline Knowing the manager confidant to express work problems & & \\
\hline $\begin{array}{l}\text { Knowing the manager confidant to express personal and } \\
\text { family problems }\end{array}$ & & \\
\hline $\begin{array}{l}\text { The manager's perception of employee's problems and } \\
\text { challenges }\end{array}$ & & \\
\hline $\begin{array}{l}\text { Organizational intellectual and mental support of the } \\
\text { employee }\end{array}$ & \multirow{2}{*}{$\begin{array}{l}\text { Employee's } \\
\text { empowerment }\end{array}$} & \multirow[t]{2}{*}{4} \\
\hline The organization's knowledge support of the employee & & \\
\hline Right and accurate work doing & \multirow{3}{*}{$\begin{array}{l}\text { Employee's job } \\
\text { productivity }\end{array}$} & \multirow{3}{*}{5} \\
\hline Timely performing organizational tasks & & \\
\hline $\begin{array}{l}\text { Doing right and consistent works with organizational goals } \\
\text { throughout the day }\end{array}$ & & \\
\hline The employee's normal conditions psychologically & \multirow{3}{*}{$\begin{array}{l}\text { The employee's mental } \\
\text { and mental conditions }\end{array}$} & \multirow{3}{*}{6} \\
\hline $\begin{array}{l}\text { The employee's ability to manage mental and } \\
\text { psychological problems during work }\end{array}$ & & \\
\hline $\begin{array}{l}\text { The employee's healthy and happy family life outside the } \\
\text { organization }\end{array}$ & & \\
\hline The employee's satisfaction with the manager & \multirow{4}{*}{$\begin{array}{l}\text { The employee's job } \\
\text { satisfaction }\end{array}$} & \multirow{4}{*}{7} \\
\hline The employee's satisfaction with colleagues & & \\
\hline The employee's satisfaction with salary policies & & \\
\hline Perceived organizational justice by employee & & \\
\hline $\begin{array}{l}\text { The employee's physical fitness conditions to complete } \\
\text { full-time working hours }\end{array}$ & \multirow{2}{*}{$\begin{array}{l}\text { The employee's suitable } \\
\text { physical conditions }\end{array}$} & \multirow[t]{2}{*}{8} \\
\hline No acute and chronic illness for employee & & \\
\hline $\begin{array}{l}\text { The employee's belief in that if the client's job is done fast, } \\
\text { he/she will not be grateful }\end{array}$ & \multirow{3}{*}{$\begin{array}{l}\text { The employees' laziness } \\
\text { in organizational matters }\end{array}$} & \multirow{3}{*}{9} \\
\hline $\begin{array}{l}\text { The employee's belief in that he/she will be given more } \\
\text { jobs if the organization's tasks are carried out promptly }\end{array}$ & & \\
\hline The employee's very low useful working time during a day & & \\
\hline $\begin{array}{l}\text { The senior management's attention to the laziness and } \\
\text { procrastination of employees in doing organizational works }\end{array}$ & \multirow{3}{*}{ Organizational factors } & \multirow{3}{*}{10} \\
\hline $\begin{array}{l}\text { The organizational policies and strategies to combat } \\
\text { employees' laziness and procrastination }\end{array}$ & & \\
\hline $\begin{array}{l}\text { Organization's careful monitoring to prevent laziness and } \\
\text { procrastination of employees in doing their job }\end{array}$ & & \\
\hline $\begin{array}{l}\text { The employee's personality characteristics consistency } \\
\text { with his/her role in the organization }\end{array}$ & \multirow{2}{*}{$\begin{array}{l}\text { Job fitness with } \\
\text { employee's personality }\end{array}$} & \multirow{2}{*}{11} \\
\hline $\begin{array}{l}\text { The employee's behavioral characteristics alignment with } \\
\text { the atmosphere and culture of the organizational unit }\end{array}$ & & \\
\hline Fairness of the payroll system & \multirow{2}{*}{$\begin{array}{l}\text { Reform of the services } \\
\text { compensation system }\end{array}$} & \multirow{2}{*}{12} \\
\hline Considering bonuses for efficient employees & & \\
\hline
\end{tabular}




\begin{tabular}{|c|c|c|}
\hline $\begin{array}{l}\text { The senior employees belief in that much work does not } \\
\text { lead to material and spiritual rewards in the organization }\end{array}$ & \multirow{2}{*}{ Work experience } & \multirow{2}{*}{13} \\
\hline $\begin{array}{l}\text { The senior employees belief in that their efforts are not } \\
\text { seen }\end{array}$ & & \\
\hline Achieving career goals & \multirow{2}{*}{ Career path } & \multirow{2}{*}{14} \\
\hline The employees' clear goals and career path & & \\
\hline The employees' appropriate guidance & \multirow{2}{*}{ leadership style } & \multirow{2}{*}{15} \\
\hline The employees' participation in decision-making processes & & \\
\hline Paying attention to the efforts of employees by managers & \multirow{2}{*}{$\begin{array}{l}\text { The employees' } \\
\text { motivation }\end{array}$} & \multirow{2}{*}{16} \\
\hline Considering incentives for efficient employees & & \\
\hline $\begin{array}{l}\text { The existence of fair rules and regulations in the } \\
\text { organization }\end{array}$ & \multirow[t]{2}{*}{ Governmental factors } & \multirow[t]{2}{*}{17} \\
\hline Considering employees' work effects & & \\
\hline Existence of appropriate strategies and programs & \multirow{4}{*}{$\begin{array}{l}\text { Organizational } \\
\text { productivity }\end{array}$} & \multirow{4}{*}{18} \\
\hline Determining group and individual goals by managers & & \\
\hline $\begin{array}{l}\text { Delegation of authority and supporting innovative ideas of } \\
\text { employees in the organization }\end{array}$ & & \\
\hline Providing information and funding & & \\
\hline
\end{tabular}

In this stage of analysis, the next important step was to put the identified categories on the paradigmatic model. A paradigmatic model helps the researcher know how to put categories. The general structure of the paradigmatic model can be seen in Fig. 1.

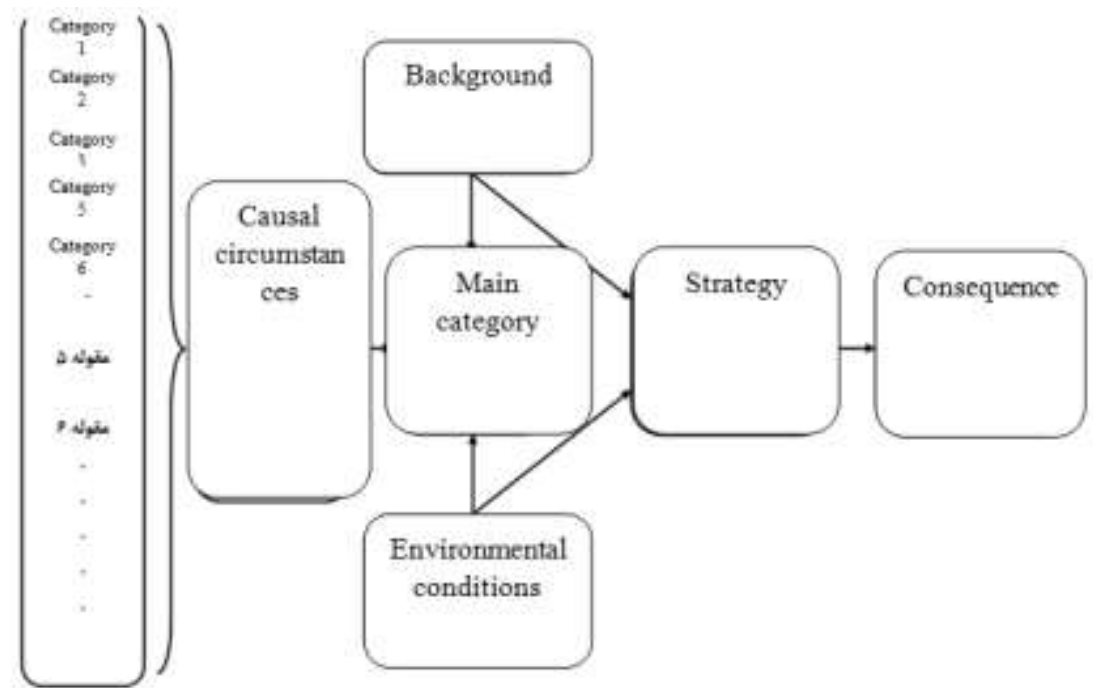

Figure 1: Paradigmatic model (Bazargan, 2008: 102) 


\section{Conclusion}

In this section, each dimension of the paradigmatic model is discussed and the related categories are introduced:

The main category (axial) is an idea, an incident or an event in which concepts and categories are created base on its axis. In this research, and given the goals and categories identified, the category of "laziness and procrastination in doing of organizational works" was considered as the main category. That is the core of the conceptual model is to focus on the phenomenon of laziness and procrastination in doing of organizational works.

\section{Causal conditions: are the set of conditions that led to the emergence of the phenomenon.}

Categories related to this dimension was determined as follows:

- Employee's organizational commitment: This category refers to the fact that the employees' commitment of the manager, to the client, and to their colleagues may be considered as one of the factors contributing to laziness and procrastination in organizational works.

- $\quad$ The quality of the employee's relationship with the manager: this category refers to this that the type of relationship and the degree of employee's intimacy with his direct manager could possibly be one of the factors contributing to laziness and procrastination in organizational works.

- The employee's mental and psychological conditions: This category refers to the fact that the employee's mental and psychological conditions, the quality of personal life, and the ability to manage mental and psychological challenges can be considered as one of the factors contributing to laziness and procrastination in organizational works.

- The employee's job satisfaction: This category refers to this that employee's satisfaction with the manager, colleagues and organizational justice may be considered as one of the factors contributing to laziness and procrastination in organizational works.

- Job fitness with employee's personality: This category refers to the fact that the fitness and consistency of the employee's personality and morale with job and organizational role may be considered as one of the factors contributing to laziness and procrastination in organizational works.

- Work experience: This category refers to the fact that some of the senior employees, considering their work experience and familiarity with the organization, believe that their efforts have not been well seen by managers during these years and this factor could possibly be one of the factors contributing to laziness and procrastination in organizational works. 
- Leadership Style: This category refers to this that the extent to which employee participate in decision-making, and employees' appropriate guidance by managers is likely to be one of the factors contributing to laziness and procrastination in organizational works.

Ground: Represents the special circumstances in which the phenomenon (main category) is located. Ground also includes the characteristics of the original category. In the present study, according to the goals and categories identified, the category of "organizational factors" and "governmental factors" were considered as the ground categories. Organizational factors refer to the view of senior management of the organization, policies and macro strategies, as well as the organization's regulatory system on employees' laziness in organizational works. Also, governmental factors refer to laws and regulations as well as the work effects associated with the employee.

Environmental conditions: Are extended structural field and external factors that can affect the main category. In this study, according the goals and categories identified, the category "cultural, social and economic factors of society" was considered as an environmental category. This means that social, cultural and economic conditions governing the governmental organizations and society can probably be considered as one of the factors contributing to laziness and procrastination in organizational works.

Strategies: A specific set of strategies or actions is possible in a given background and with specific mediator conditions. In fact, strategies are actions that can turn the main category into consequences. In this research, given to the goals and categories identified, the categories of "employee empowerment", "reform of the services compensation system" and "employees' motivation" were considered as strategic categories. Employee empowerment means that intellectual and knowledge support for employees may be considered as one of the factors contributing to laziness and procrastination in organizational works. reform of the services compensation system did not mean that the lack of an efficient and motivational payroll system is likely to be one of the factors contributing to laziness and procrastination in organizational works. The employees' motivation, both materially and spiritually, can affect the employees' laziness in organizational works.

Consequences: It refers to the consequences of the realization of a axial category in the context of the causal, environmental, and ground conditions and through specific strategies. In the present study, according to the goals and categories identified, the categories 
of "employee's job productivity" and "organizational productivity" were considered as consequential categories.

The next step was to put the categories in a paradigmatic model that caused the identification of the conceptual model of the research. The main structure of the model can be seen in Fig. 2 .

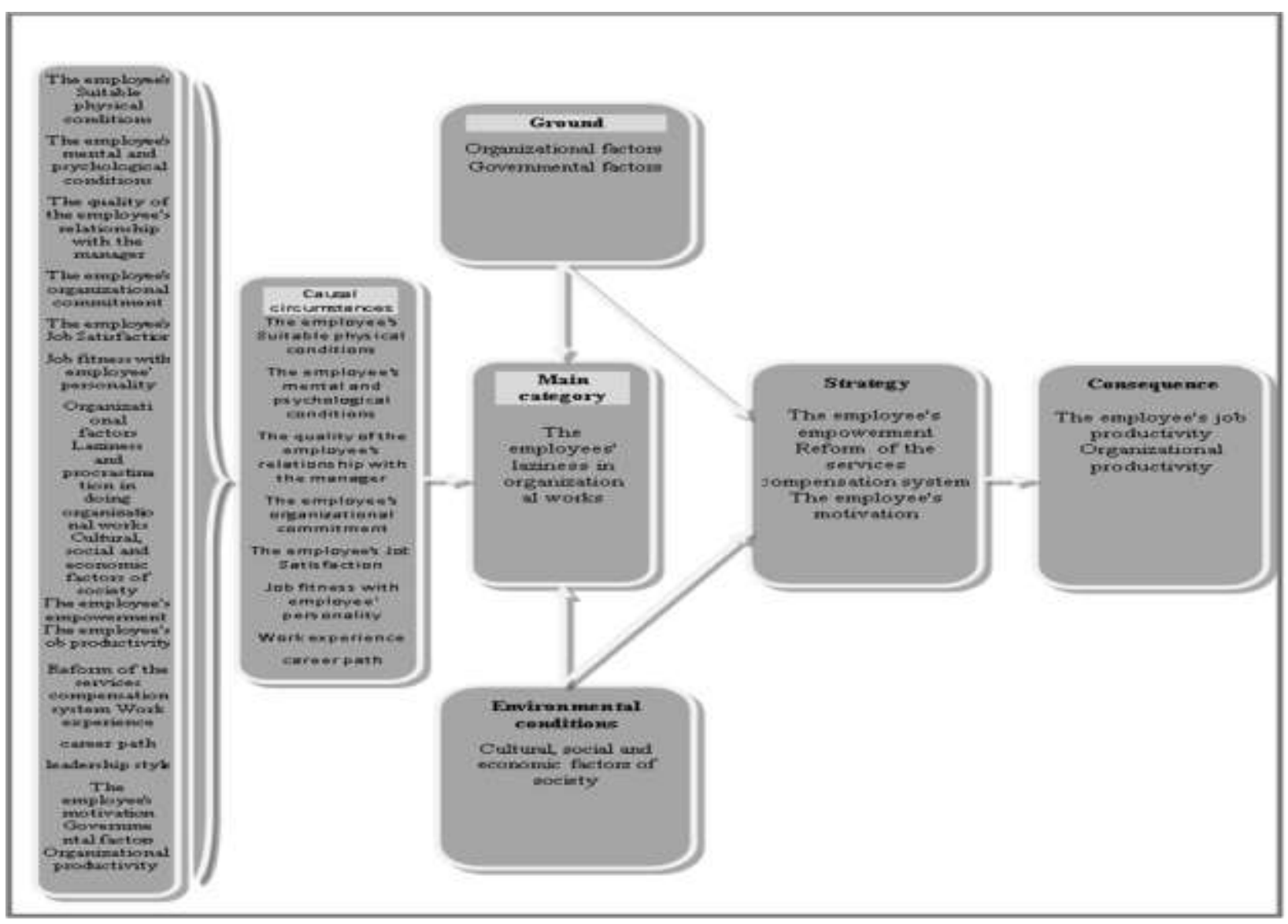

Figure 2: Conceptual model of research

In this regard, according to the experience gained in this research, future researchers are suggested to take stapes to explain the conceptual model derived from this research in a vast community and try to test the conceptual model of this study using quantitative methods such as structural equation modeling.

\section{References}

Bazargan, Mahdi (Abdollah Motaghi). (1978). Iranian Adaptation: Adjoint Season of the Spirit of Nations. Tehran: yad.

Danesh, Salem; Noor Mohammadian, Mojdeh; Abdollahi, Ayoub. (2016). Investigating the Relationship Between Personality Type and Job Burnout and Procrastination of Head 
Masters in Lashar Area, The First International Conference on Modern Research in the Field of Education Sciences, Psychology and Social Studies of Iran, Qom, Permanent Secretariat of the Conference.

Fang, Chen., Limin, Zhang., Joseph, Latimer. (2014). How much has my co-worker contributed? The impact of anonymity and feedback on social loafing in asynchronous virtual collaboration, International Journal of Information Management, Volume 34, Issue 5, pp. 652-659.

Fayazi M, Kaveh, M. (2009). Procrastination Tomorrow syndrome. Magazine of tomorrow planning of Magazine, P. 205. [Persian].

Hajizadeh Ebrahimi, Fazel. (2015). Investigating the Effect of Knowledge Management on the Trust and Social Loafing of Mellat Bank Employees, National Conference on Management Ocean, Shiraz, Center for the Development of Modern Education in Iran (METANA).

Jahangiri, Fahimeh. (2016). Investigating the Relationship Between Managerial Styles and Managerial Job Procrastination, Fifth International Conference on Psychology and Social Sciences, Tehran, Hamayeshgaran-e-Mehr-e-Eshragh .

Jazani, Nasrin (2015). Human Resource Management, Tehran: Ney Publication.

Khodabakhshi, Mahdi; Sepahvandi, Mohammad Ali; Sheikholeslami, Ali; Habibi, Elham (2015). Prediction of organizational Procrastination and Life Satisfaction Based on Job Burnout

and Work Experience, Journal of Military Medicine, Vol. 17, Issue 4, pp. 207-231.

Metin, U. Baran., Taris, Toon W., Maria C.W. Peters. (2016). Measuring procrastination at work and its associated workplace aspects, Personality and Individual Differences, Volume 101, pp. 254-263.

Saadat, Esfandiar. (2016). Human Resources Management, Tehran: Organization for the Study and Compilation of Humanities Books of Universities (SAMT).

Sepahvand, Reza; Mohammadyari, Zohreh. (2015). Identification of the Mentality of Individuals Towards Organizational Laziness Using Q-methodology, Journal of Organizational Behavior Studies, Vol. 4, Issue 3, pp. 1-30.

Shul, Sedigheh (2013). Investigating the Causes of Under-activation of Employees in Iranian Governmental Organizations, Master's Thesis, Tarbiat Modares University, Faculty of Economic Affairs, Tehran.

Takallu, Farideh; Ahmadi, Kiyomars; Ziapoor, Arash. (2015). The Study of the Relationship Between the Components of the Big Five Personality Traits and Social Loafing in the Staff of the University of Medical Sciences in 2014, Journal of Clinical Research in Medical Sciences, Vol. 4, Issue 1, pp. 43-51. 
Wohl MJ, Pychyl TA, Bennett SH. (2010). I forgive my-self, now I can study, How selfforgiveness for procrastinating can reduce future procrastination. Personality and Individual Differences. 48: 803-808.

Yavari, Joseph; Talkhi, Kobra. (2016). The Relationship Between Procrastination and Productivity Among Faculty Members of Physical Education, The First National Conference on the Development of Sport Science in the Field of Health, Prevention and Heroism, Qazvin, Imam Khomeini International University.

Yekkeh Fallah, Mohammad; Dameshghi Asayesh, Soleiman; Mostafa, Mostafa, Soghra Maleki (2016). Effectiveness of Treatment Based on Islamic Teachings and Concepts in Reducing procrastination, Fourth National Conference on Sustainable Development in Educational Sciences and Psychology, Social and Cultural Studies, Tehran, Mehr Arvand Institute of Higher Education, Center for Solutions to Access Sustainable Development.

Yekkeh Fallah, Mohammad; Hossein Khani, Mohammad; Mohtadi, Mohammad Hassan; Karimzadeh, Sudabeh. (2015). Comparison of Social Loafing in Two Groups of Public and Private Jobs in Tehran, National Symposium on Scientific Understanding of Morality Hosseini, Taybad city, General Council and the Department of Culture and Islamic Guidance.

Zhenpeng Luo., Hailin Qu., Einar Marnburg. (2013). Justice perceptions and drives of hotel employee social loafing behavior. International Journal of Hospitality Management, Volume 33, pp. 456-464. 